\title{
BALANCE SCORECARD ANALYSIS AS A COMPANY PERFORMANCE MEASUREMENT TOOL
}

\author{
Resti Kusmalasari ${ }^{1}$, Audita Setiawan ${ }^{2,}$ Asep Effendi ${ }^{3}$ \\ ${ }_{1,2,3}$ Universitas Sangga Buana \\ ${ }^{1}$ correspondence : restikusmalasari20@gmail.com
}

\begin{abstract}
The research was conducted with the aim of knowing the performance of banking companies using the Balanced Scorecard method. This study aims to obtain an overview of performance benchmarks with the Balanced Scorecard approach using four perspectives: finance, customers, internal business, growth and learning in one of the Perumda Rural Banks in West Java from 2017 to 2020. This type of research is a case study that is explained one by one using four perspectives. The type of data used is qualitative data with data sources derived from primary data and secondary data. The data analysis technique uses a descriptive method with accounting approach where data is used in the form of numbers and then interpreted and described, so as to obtain research results based on the calculation of the Balanced Scorecard. The result of this research shows that Perumda Rural Banks studied are still categorized as poor with the BBB category, the performance still needs to be improved so that the company can achieve excellent performance or healthy. In addition to this, it is recommended for companies to apply the Balanced Scorecard to be able to assist companies in measuring performance not only from the financial aspect but also considering the performance from non-financial aspects.
\end{abstract}

Keywords: Financial Perspective, Customer, Growth and Learning, Internal Business Process.

\section{INTRODUCTION}

The banking world is currently very broadly developed, so this has a positive influence in encouraging economic growth in Indonesia. Banking companies continue to emerge so that in this situation banking companies demand management to work more effectively in developing their banking business. Management can directly supervise banking companies so that they always grow and are always trusted by the whole community because banking is a financial institution that functions to collect and distribute public funds and aims to support the implementation of national development in order to increase equitable development and economic growth and national stability towards improvement people's standard of living.
Performance measurement aims to determine the contribution of a part of the company to the company's organization as a whole, provide a basis for assessing the quality of performance within the company, and provide motivation [1]. Performance effectiveness is the implementation of plans for achieving goals by Human Resources who have the ability, competence and motivation to build a more advanced banking system. In carrying out all activities to aim at the effectiveness of performance, supervisors or monitoring are carried out to measure and assess the extent to which the effectiveness of the performance has been carried out.

Performance measurement is one of the most important factors for a company. These measurements can be used to assess the success of the company as well as the basis for the preparation of performance. Performance 
measurement only focuses on the final result, namely the financial aspect. This method seeks to balance the measurement of financial aspects with non-financial aspects which are generally called the Balanced Scorecard by applying this method the banking companies management will be able to measure the effectiveness of banking performance. The Balanced Scorecard has advantages that make it a management system in banking more comprehensive.

Perumda Rural Bank is one of the Government-owned banks whose capital is provided directly by the Government and based on Government Regulation of the Republic of Indonesia No. 54 of 2017 Regional Owned Enterprises, abbreviated as BUMD, are business entities whose capital is wholly or most of the capital is owned by the Regions. As a Rural Bank whose ownership is the government, the Bank's Soundness Level is one of the references to assess the effectiveness of performance and performance degradation which will later be reported to the owner, namely the Mayor and the Financial Services Authority as banking supervisor. In its report, Perumda Rural Banks is still not said to be maximal in its performance because there is always a decrease in performance standards every year. The decline in the performance of Perumda Rural Banks in the last 4 years, namely 2017 to 2020 and cannot be said to be effective and efficient for management, especially in measuring the effectiveness of performance and the achievement of performance effectiveness which aims to determine the implementation of activities in supporting the effectiveness of banking companies.

\section{LITERATURE REVIEW}

\section{Performance}

Performance is the rater level that will measure the success of a company. Performance is an achievement achieved by a person in carrying out the tasks and functions given [2]. Performance is the rater level that will measure the success of a company.

\section{Performance measurement}

To ensure that resources are used effectively and efficiently to achieve company goals, it is necessary to measure management performance. Performance measurement is a process of recording and measuring the achievement of the implementation of activities in the direction of achieving the mission through the results displayed in the form of products, services, or a process [3].

\section{Performance Standard}

Performance standards are the requirements of the task functions that are set as targets that must be achieved. There are three types of performance criteria, namely: [4]

1. Performance based on traits, which are judged on personal characteristics.

2. Performance based on behavior, professional relationship.

3. Performance based on results, focus on what it will achieve. 


\section{Performance Standard Function}

Performance standards have the following functions: [5]

1. As a benchmark to determine the success and failure of performance.

2. Motivation to work harder to achieve performance standards.

3. Provide direction for the implementation of the work to be achieved.

4. Provide guidelines regarding the work implementation process to achieve performance standards.

\section{Performance Rating}

There are two main requirements that are treated in order to conduct an effective performance appraisal, namely the existence of performance criteria that can be measured objectively and the existence of objectivity in the evaluation process [6].

\section{Purpose of Performance Measurement}

Performance measurement has the main objective, namely to motivate employees in achieving organizational goals and in complying with predetermined standards of behavior, in order to produce the desired actions and results. The benefits of the performance measurement system are as follows: [7]

1. Manage the organization's operations effectively and efficiently through maximum employee motivation.

2. Assist in making decisions related to employees such as promotions, terminations, and transfers.
3. Identify employee training and development needs and.

4. Provide feedback to employees on how their supervisors rate performance.

5. Provides a basis for award distribution.

\section{Characteristics of Performance}

\section{Measurement System}

With the emergence of new paradigms where businesses must be driven by a consumer focus, an effective performance measurement system must at least have the following requirements: [1]

1. Based on each activity and organizational characteristics according to the customer's perspective;

2. Evaluate various activities, using consumer-validated performance measures:

3. In accordance with all aspects of the performance of activities that affect customers, resulting in a comprehensive assessment;

4. Provide feedback to help all members of the organization identify problems that have potential for improvement.

\section{Balanced Scorecard}

According to [8] Balanced Scorecard is a planning and management system that is used in an organization, both profit-oriented and not-for-profits, in aligning vision and strategy to improve internal and external communication and overseeing organizational performance in accordance with its strategy by placing four perspectives, namely Financial Perspective (Financial 
Perspective), Customer Perspective, Internal Process Perspective, Learning and Growth Perspective.

\section{Goals of the Balanced Scorecard}

Financial and non-financial components are carried out to optimize financial performance. In public organizations, it can be adapted to produce measurements that are in accordance with the main goals of the organization. [9]

\section{Weaknesses of Balanced Scorecard}

Some of the weaknesses of the Balanced Scorecard [10]:

- There is a poor relationship between the size of the non-financial perspective with the results obtained. Future profits are not guaranteed to always follow targets from a non-financial perspective.

- There is no financial performance mechanism so that managers are more concerned with the financial aspects of the company than other aspects.

- There is no mechanism for improvement for the company. Many companies do not have alternative ways to improve their goals so that this becomes a weakness.

- Measures are not up to date. Not having a formal mechanism for updating measures is an obstacle that is often faced by many companies so that they are still using measures on the old strategic basis.

- Too many measurements used by a company (measurement overload). The size used by managers will usually lose focus so that the company's success will be difficult to achieve.

\section{Advantages of Balanced Scorecard}

The advantages of the Balance Scorecard [1] are as follows:

The Comprehensive Balance Scorecard expands the perspectives covered in strategic planning that were previously limited to the financial perspective and extends to other perspectives.

- Coherent Balance Scorecard requires personnel to build causal relationships between the various objectives generated in strategic planning. Every strategic goal that is set from a non-financial perspective must have a case-by-case relationship with the financial goals, either directly or indirectly.

- Balance Scorecard (balanced) balance between strategic targets in perspective because performance measurement using the Balance Scorecard concept does not only pay attention to the financial aspects of the company but also non-financial aspects such as customers, internal business processes and learning and growth.

- Measurable all the strategies set out in each perspective of the Balance Scorecard have their respective benchmarks. The existing strategic targets from a non-financial perspective are not easy to measure, but with the Balance 
Scorecard approach, non-financial strategic targets are determined so that the results can be managed and evaluated and the results can be identified on the performance of the financial perspective.

\section{METHOD}

The data collection technique used is technical documentation in the form of documents and archives that are relevant to the research objectives obtained from existing records/documents in the form of company organizational structures, financial reports, notes and forms. Data analysis technique using descriptive analysis is an activity to interpret, compile, classify and interpret the data so as to provide an overview of the problems faced or researched. The descriptive method of accounting approach using balanced scorecard analysis includes the following steps:

- Calculating the financial perspective score of money is related to the company's financial statements. This analysis is obtained by calculating the company's financial performance, namely ROA, LDR, BOPO, NPM.

- Calculating customer perspective scores by comparing the number of customer acquisitions such as: market share, retention, customer/customer acquisition.

- Calculating the internal business process perspective score by calculating transaction efficiency to customers, AETR (Administrative Expense to Total Revenue).

- Calculating a learning and growth perspective score by calculating the length of time Education and training time.

- After all perspectives are known to score each, the next step is to calculate the balanced scorecard score from the four perspectives.

- After the balanced scorecard score is known, it can be assessed that the score is located in the specified quadrant/coefficient.

- Conduct analysis and draw conclusions from research results. 
Table 1 : Definition and Operational Variable

\begin{tabular}{|c|c|c|c|c|}
\hline No & Variable & Concept Definition & $\begin{array}{r}\text { Data } \\
\text { source }\end{array}$ & Indicator \\
\hline 1 & Financial perspective & $\begin{array}{l}\text { Perspective finance which illustr } \\
\text { ates the consequences of the } \\
\text { actions economies are taken } \\
\text { in financial indicators }\end{array}$ & $\begin{array}{r}\text { Financial } \\
\text { statements }\end{array}$ & 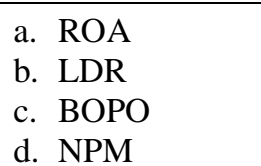 \\
\hline 2 & Customer perspective & $\begin{array}{l}\text { The customer perspective define } \\
\text { s customers and market segment } \\
\mathrm{s} \\
\text { where the business unit will com } \\
\text { pete }\end{array}$ & $\begin{array}{l}\text { NoA Data } \\
\text { Report } \\
\text { (Number Of } \\
\text { Account })\end{array}$ & $\begin{array}{l}\text { a. Market Share } \\
\text { b. Retention } \\
\text { c. Customer } \\
\text { d. Acquisition }\end{array}$ \\
\hline 3 & $\begin{array}{l}\text { Internal business } \\
\text { process perspective }\end{array}$ & $\begin{array}{l}\text { The internal business process } \\
\text { perspective describes the interna } \\
\text { l processes required to provide } \\
\text { value for customers and owners }\end{array}$ & $\begin{array}{l}\text { Operations } \\
\text { Manager } \\
\text { Report }\end{array}$ & $\begin{array}{l}\text { a. Efficiency of } \\
\text { transactions to } \\
\text { customers. } \\
\text { b. AETR }\end{array}$ \\
\hline 4 & Learning and growth & $\begin{array}{l}\text { The learning and growth perspec } \\
\text { tive defines the capabilities } \\
\text { parent organizations } \\
\text { need to create } \\
\text { long term growth and improvem } \\
\text { ent }\end{array}$ & $\begin{array}{c}\text { HR and } \\
\text { General } \\
\text { Manager } \\
\text { Report }\end{array}$ & $\begin{array}{l}\text { Length } \\
\text { of education } \\
\text { and training time }\end{array}$ \\
\hline
\end{tabular}

\section{RESULTS AND DISCUSSION}

The data analysis in this research is descriptive which aims to describe, classify and interpret the research results. Performance measurement according to the balance scorecard in a financial perspective in particular will be analyzed on the company's position in its business cycle. The position of Perumda Rural Bank as one of the banking offices is in the stage of survival (sustainability), this is indicated by the company's activities that are still conducting investment and reinvestment activities. Prior to analysis and calculations from the perspective of finance, customers and growth and learning and internal business processes.

- Financial Perspective

The company's Return On Assets in 2017 a score of $\mathrm{D}$ means that it is caused by unstable earnings on income then followed by a decrease in total asset turnover. In 2018 to 2020 the score to C means the company is able to increase profits. The increase in income is due to the fact that banks are able to improve product and service services to customers, but when viewed from the average value of Perumda Rural Banks Return On Assets is classified as category D (Not Healthy) which means there is no effectiveness in managing assets to generate maximum profit because in 2017 Perumda Rural Banks had a very low value so that in the following years it had to cover this low value.

Loan to Deposit Ratio from 2017 to 2018 the LDR ratio according to the provisions of the Financial Services Authority must be less than $94.75 \%$. Perumda Rural Bank is very good and can be viewed from the average it can be stated healty this is because there is an increase in third 
party funds from savings and deposits accompanied by an increase in total credit given to customers so that achievement in the distribution of targets is achieved. This shows that Perumda Rural Banks are able to repay the withdrawal of funds made by depositors by relying on loans provided as a source of liquidity.

Operating Expenses and Operating Income (BOPO) operating costs can be calculated based on the sum of the total interest expense and total operating expenses. Operating income is the sum of total interest and other total operating income according to the provisions of the Financial Services Authority, the value of BOPO must be less than $93.53 \%$. From the table above, in 2017 got a score of D (Not Healthy) because due to uncontrolled operational costs issued by the company in 2018 it got a score of $\mathrm{C}$ (Health Enough) slightly on improvement in controlling costs and in 2019 it got a score of B (Health) This was due to an increase in operating income derived from credit disbursement which was quite large in number and quite effective in cost control. However, in 2020 it decreased due to the occurrence of unexpected cost control and reduced income due to the absence of credit disbursement and credit distribution so that in 2020 it received a C score (Sufficiently Healthy), in terms of the average value of Perumda Rural Banks from Overall, they got the BOPO score with a score of D which was declared (Not Healthy) because according to the standards of the Financial Services Authority the BOPO value must be less than $93.52 \%$ due to the absence of effective cost control and the absence of fixed income from Perumda Rural Banks.

The company's Net Profit Margin in 2017 to 2018 resulted in a D score meaning that its performance was not good due to the achievement of the company's net profit not being able to generate the desired net profit but in 2019 and 2020 the Net Profit Margin score $\mathrm{C}$ score meaning the performance was quite good due to by the company's net income the company has been able to generate the desired net profit. Judging from the average values, the company's Net Profit Margin is classified as a score of $\mathrm{C}$ (Health Enough)) which means that its performance is quite good due to the low ability of the company's management to obtain net income above the costs incurred so that the company has not been able to generate maximum net profit.

- Customer Perspective

Perumda Rural Bank's market share shows an increase from 2017 to 2019 although in 2020 it has decreased but when viewed from the average value has a B score which means the bank is able to control market share well from the results of service income for product services and services. services that have 
been provided to customers. The market share of Perumda Rural Banks has increased although not significantly because the bank is able to dominate a large market share by developing supporting infrastructure, namely by adding cash offices to acquire new customers. The Bank also always strives to improve the quality of fund and credit products as well as better service quality to its customers.

Retention increase from 2017 to 2018 was due to the addition of new customers so that Perumda Rural Banks was able to provide good service from the previous year. However, in 2019 and 2020, there was another decline in customers due to the lack of promotions and facilities provided by Rural Banks to the public regarding the awareness of the Bank. The bank has also made future plans in order to attract people to save at the Perumda Rural Bank.

Acquisition of customers/customers Perumda Bank Perkreditan Rakyat got a score of C (Good Enough) from 2017 to 2020 and in terms of the average Perumda Bank Perkedit Rakyat also had a score of $\mathrm{C}$ (Health Enpugh) which means a decrease in customers/customers occurred every year due to the absence of good facilities or services for customers due to the absence of ATM or Mobile Banking facilities owned by the bank. However, the bank has also made future plans in order to attract customers by facilitating access to make transactions by promoting it to the entire community.

- Internal Business Process Perspective In calculating EMR, if the resulting ratio is close to 1 then the company in carrying out operational activities has been efficient and vice versa if the resulting ratio is smaller than 1 then the company is not operating efficiently. Based on the results of the calculation of the EMR obtained 0.71 this indicates that the level of efficiency of Perumda Rural Banks in carrying out the transaction process is good with a score of $\mathrm{B}$. This is because the employees of the Perumda Bank Perkreditan Rakyat have been effective in their work so that the internal processes that occur have supported the expertise of their employees.

AETR ( Administrative Expense to Total Revenue) each year has decreased significantly but in terms of the average value of Perumda Rural Banks still has a pretty good score, namely with a score of B (Healthy) thus it can be concluded that AETR (Administrative Expense to Total Revenue) can be said to be effective and efficient because administrative costs or marketing costs for products and services as well as other office administration costs can be controlled so that they can still survive at a fairly good score. 
- $\quad$ Learning and Growth Perspective

The average length of time for education and training attended by employees in 2017 was 1 hour per month for each employee, in 2018 it was 7.8 hours per month for each employee, and in 20198 hours per month for each employee (up 2.56\%), and in 2020 for 8.1 hours per month for each employee (1.25\%). In conclusion, from the results of the learning and growth perspective, it can be said that the company is good with a B score in carrying out the learning process. This can be seen from the activities in the field of information and technology that make it easier for company employees to work. Activities in the field of information have contributed quite heavily in supporting operational activities.

Table 2 : Perspective Indicator Score

\begin{tabular}{|c|c|c|c|c|c|c|c|c|}
\hline \multirow[b]{2}{*}{ Perspective } & \multirow[b]{2}{*}{$\begin{array}{c}\text { Total- } \\
\text { Ah } \\
\text { Indic- } \\
\text { Ator }\end{array}$} & \multicolumn{3}{|c|}{ Maximum Weighted Score } & \multirow[b]{2}{*}{$\begin{array}{c}\text { Compo- } \\
\text { Nen } \\
\text { Final } \\
\text { Value }\end{array}$} & \multicolumn{3}{|c|}{ Final Score } \\
\hline & & $\begin{array}{c}\text { Maxi- } \\
\text { Mal } \\
\text { Indic- } \\
\text { Ator } \\
\text { Score }\end{array}$ & $\begin{array}{l}\text { Indicator } \\
\text { Weight }\end{array}$ & $\begin{array}{c}\text { Maximal } \\
\text { Bang- } \\
\text { Scoring }\end{array}$ & & $\begin{array}{c}\text { Total } \\
\text { Score } \\
\text { Indicator }\end{array}$ & $\begin{array}{l}\text { Indicator } \\
\text { Weight }\end{array}$ & $\begin{array}{l}\text { Weighted } \\
\text { Score }\end{array}$ \\
\hline Finance & 4 & 4 & 15.00 & 240 & $56.25 \%$ & 9 & 15.00 & 135.00 \\
\hline $\begin{array}{l}\text { Customer / } \\
\text { Customer }\end{array}$ & 3 & 4 & 25.00 & 300 & $66.67 \%$ & 8 & 25.00 & 200.00 \\
\hline $\begin{array}{l}\text { Internal } \\
\text { Business } \\
\text { Process } \\
\end{array}$ & 2 & 4 & 10.00 & 80 & $75.00 \%$ & 6 & 10.00 & 60.00 \\
\hline $\begin{array}{l}\text { Growth and } \\
\text { Learning }\end{array}$ & 1 & 4 & 5.00 & 20 & $75.00 \%$ & 3 & 5.00 & 15.00 \\
\hline \multicolumn{4}{|c|}{ MAXIMUM TOTAL SCORE } & 640 & \multicolumn{3}{|c|}{ TOTAL WEIGHTED SCORES } & 410 \\
\hline \multicolumn{9}{|c|}{$\begin{array}{l}\text { TOTAL SCORE }=(\text { Number of order scores/Maximum Total Weighted Score }) \times 100 \%=(410 / 640) \times \\
100 \%=\mathbf{6 4 . 4 0} \%\end{array}$} \\
\hline
\end{tabular}

Primary data sources that have been obtained from 2017 to 2020

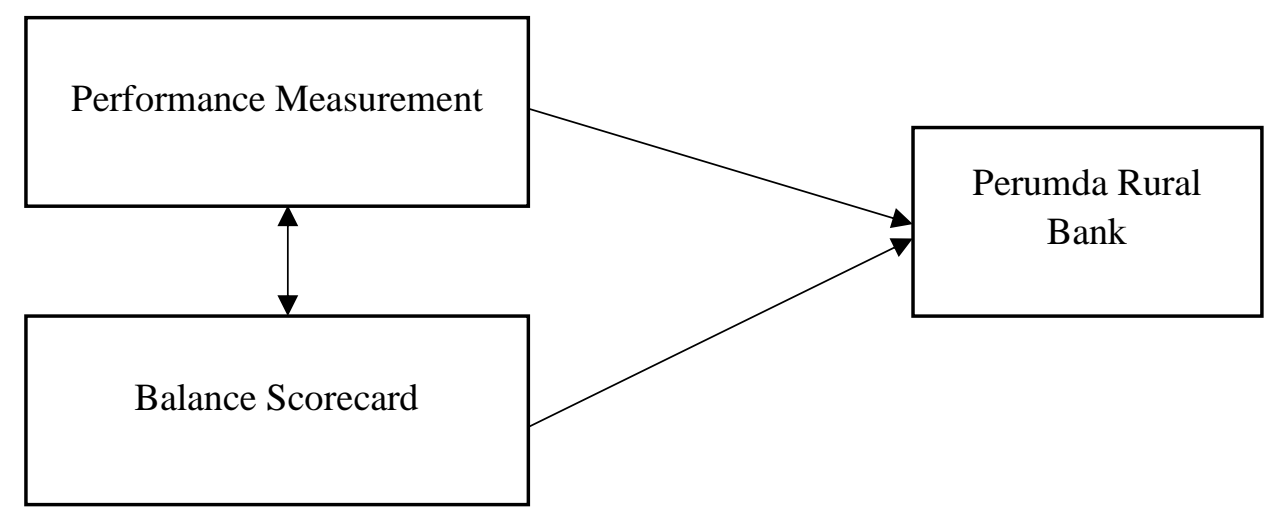

Figure 1: Research Paradigm 


\section{CONCLUSION}

The results of the calculation of the balance scorecard, it can be seen that the performance of Perumda Rural Banks is Less Good or called Unhealthy with the BBB category and this performance still needs to be improved so that the company is able to achieve excellent performance. The financial perspective has a poor performance with BBB. This means that the company has not been able to achieve optimal financial performance. The customer's perspective has very good performance, meaning that the company has been able to optimize customer performance by making improvements to the marketing strategy. The internal process perspective has very good performance with category A, which means the company has optimized its internal business processes. The learning and growth perspective has very good performance with category A meaning the company has excellent learning and growth with the three perspectives that can be categorized as very good, so the company can support improvement from all three perspectives so that in the future it can produce good/healthy performance.

\section{REFERENCES}

[1] Mulyadi, Balance Scorecard Conte,porary Tool For Multipling Financial Performance, Jakarta: Salemba Empat, 2007.

[2] Mangkunegara, Evaluation of Human Resources Performance, Bandung: Refika Aditama, 2009.

[3] S. L, Performance Measurement Guide, New Jersey: Prentice-Hall, 1993.

[4] R. Schuler, Human Resources Management 6 th Edition Indonesia Traslation, Jakarta: Erlangga, 1999.

[5] M. Abdulah, Management and Employee Performance Evaluation, Yogyakarta: Aswaja Pressindo, 2014.

[6] F. C. Gomes, Human Resorce Management Indonesia Translation, Jakarta: Andi Offset, 2003.

[7] Mulyadi, Balance Scorecard-Based Strategic Management System, Yogyakarta: UPP AMP YKPN, 2005.

[8] K. a. Norton, Balance Scorecard : Implementing Strategy Into Action Indonesia Translation, Jakarta: Erlangga, 2000.

[9] Mahsun, Public Sector Performance Measurement, Yogyakarta: BPFE, 2006.

[10] A. a. Govindarajan, Management Control System Indonesia Translation, Jakarta : Salemba Empat, 2005. 